\title{
REMOVAL OF Pb(II) IONS AND MALACHITE GREEN DYE FROM WASTEWATER BY ACTIVATED CARBON PRODUCED FROM LEMON PEEL
}

\author{
Sayed Zia Mohammadia, Mohammad Ali Karimia, Sayedeh Nasibeh Yazdy ${ }^{\mathrm{a}}$, Tayebeh Shamspur ${ }^{\mathrm{b}, *}$ and Hooshang Hamidian ${ }^{\mathrm{a}}$ \\ aDepartment of Chemistry, Payame Noor University, Iran \\ bepartment of Chemistry, Shahid Bahonar University, Kerman, Iran
}

Recebido em 04/09/2013; aceito em 04/02/2014; publicado na web em 08/05/2014

\begin{abstract}
In the present study, a high-surface area activated carbon was prepared by chemical activation of lemon peel with $\mathrm{H}_{3} \mathrm{PO}_{4}$ as the active agent. Then, the adsorption behavior of Malachite green dye and $\mathrm{Pb}(\mathrm{II})$ ions on the produced activated carbon was studied. Batch process was employed for sorption kinetics and equilibrium studies. Experimental data were fitted to various isotherm models. According to the Langmuir model, the maximum adsorption capacities of Malachite green dye and $\mathrm{Pb}(\mathrm{II})$ ions were found to be 66.67 and $90.91 \mathrm{mg} \mathrm{g}^{-1}$, respectively, at room temperature. Kinetic studies showed the adsorption process followed a pseudo second-order rate model. The sorption kinetics were controlled by intra-particle diffusion. The results indicated that the produced activated carbon can be economically and effectively used as an adsorbent for the removal of Malachite green dye and $\mathrm{Pb}$ (II) ions from wastewaters.
\end{abstract}

Keywords: malachite green; removal of lead ion; chemical activation; lemon peel.

\section{INTRODUCTION}

Dyes and heavy metals are two contaminants commonly found in the wastewater from several industries. Specifically, heavy metals are discharged by industries such as agrochemical, petrochemical, and fertilizer, ${ }^{1}$ whereas dyes are principally found in effluents from dye manufacturing industries, electroplating factories, distilleries, and food companies. ${ }^{2}$ Further, these two types of contaminants are present in wastewaters from paper and pulp factories.

Lead is a heavy metal associated with various toxic effects on the kidney, nervous, hematopoietic, and gastrointestinal systems of humans. ${ }^{3}$

Malachite green (MG), a basic (cationic) dye, is the most widely used dye for coloring purposes. ${ }^{4}$ This triarylmethane dye is widely used worldwide in the aquaculture industry as a biocide as well as in the silk, wool, cotton, leather, paper, and acrylic industries. Furthermore, it is also employed as a therapeutic agent to treat parasites, fungal, and bacterial infections in fish and fish eggs and as an antiseptic for external application on wounds and ulcers. Despite its extensive use, MG is a highly controversial compound because of its reported toxic properties, which are known to cause carcinogenesis, mutagenesis, teratogenesis, and respiratory toxicity. ${ }^{5}$ Its oral consumption is also hazardous and carcinogenic. ${ }^{5}$ However, despite the large amount of data on its toxic effects, MG is still used in aquaculture and other industries. ${ }^{6}$ Therefore, the removal of $\mathrm{MG}$ dye and $\mathrm{Pb}$ (II) ions from wastewater before discharging is necessary and very important.

The removal of color and heavy metal ions from wastewaters is one of the major problems due to the difficulty in treating such effluents by conventional treatment methods. The sorption technique has proven to be an effective process for the removal of color and heavy metal ions from wastewaters. The significant advantages of the sorption technique are its high efficiency in removing very low levels of heavy metals from dilute solutions, easy handling, high selectivity, lower operating cost, minimization of chemical or biological sludge, and regeneration of adsorbent. ${ }^{7}$

Currently, different types of adsorbents used for the removal of $\mathrm{Pb}$ (II) ions and MG dye from water include zeolites, ${ }^{8}$ metallic oxides

\footnotetext{
*e-mail: shamspur@gmail.com
}

such as manganese oxides,${ }^{9}$ ion exchange resins,,${ }^{10}$ limestone,,${ }^{11}$ chitosan, ${ }^{12}$ bagasse fly ash and activated carbon,,${ }^{13}$ lignite,,${ }^{14}$ modified carbon nanotubes, ${ }^{15}$ biosorbent, ${ }^{6,16-18}$ and produced activated carbon. ${ }^{1,13,19-29}$

In this study, lemon peel was used to prepare activated carbon as a new sorbent for the removal of $\mathrm{Pb}$ (II) ions and $\mathrm{MG}$ dye from wastewater. To the best of our knowledge, this material was never used before for this application. The effects of initial adsorbate concentration, $\mathrm{pH}$, contact time, and capacity of sorbent on the removal of $\mathrm{Pb}$ (II) ions and MG dye have been studied.

\section{EXPERIMENTAL}

\section{Instrumentation}

A Varian scanning spectrophotometer (model CARY 50 Conc) with quartz cells was employed for absorbance measurements. The absorbance value of the MG was measured at $616 \mathrm{~nm}$ (maximum absorbance). ${ }^{6}$ A Metrohm pH-meter (Model 713) with a combined glass electrode (Metrohm) was used for $\mathrm{pH}$ measurements. An IKA stirrer model KS was used for agitation of the solutions. A Centurion scientific centrifuge model 1020 D.E. (West Sussex, United Kingdom) was used to accelerate the phase separation. A SensAA GBC atomic absorption spectrometer (Dandenong, Australia) equipped with a deuterium background correction and air-acetylene burner was used for absorbance measurements according to the instrument instruction. A lead hollow cathode lamp was used as the light source at a wavelength of $283.3 \mathrm{~nm}$. The other operating parameters of the element were set according to the manufacturer recommendation.

\section{Reagents and solution}

All solutions were prepared in deionized water. A $1000.0 \mu \mathrm{g} \mathrm{mL}^{-1}$ $\mathrm{Pb}$ (II) metal stock solution was prepared by dissolving $\mathrm{Pb}\left(\mathrm{NO}_{3}\right)_{2}$ (Merck, Darmstadt, Germany) in water and acidifying it with $5 \mathrm{~mL}$ of concentrated $\mathrm{HNO}_{3}$ to prevent hydrolysis. A stock solution of malachite green $(\mathrm{MG})\left(1000.0 \mu \mathrm{g} \mathrm{mL}^{-1}\right)$ was prepared by dissolving $0.2500 \mathrm{~g}$ of MG (Merck, Darmstadt, Germany) in $250.0 \mathrm{~mL}$ of deionized water. All working solutions were prepared by diluting the stock solutions with deionized water. 


\section{Preparation of the activated carbon}

Lemon peels were washed with distilled water and dried in an oven for $2 \mathrm{~h}$ at $105{ }^{\circ} \mathrm{C}$. It was then ground and sieved to particle sizes ranging from 0.3 to $0.5 \mathrm{~mm}$. Then, the precursor was soaked for $24 \mathrm{~h}$ in a solution of phosphoric acid at a ratio of $2: 1(\mathrm{v} / \mathrm{v})$. The activated precursor was dried in an oven at $250{ }^{\circ} \mathrm{C}$, carbonized in a muffle furnace for $1 \mathrm{~h}$ at $500{ }^{\circ} \mathrm{C}$ under a current of nitrogen $\left(150 \mathrm{~cm}^{3}\right.$ $\mathrm{min}^{-1}$ ), and cooled to room temperature.

The treated samples were repeatedly washed with boiling water until a neutral $\mathrm{pH}$ was obtained and then dried at $105^{\circ} \mathrm{C}$ for $24 \mathrm{~h}$ and stored in bottles until use.

\section{Adsorption studies}

Adsorption tests for the removal of lead ions were conducted by mixing $0.1 \mathrm{~g}$ activated carbon with $20 \mathrm{~mL}$ of a solution of known concentration (50-500 $\mathrm{mg} \mathrm{L}^{-1}$ at $\mathrm{pH} 7$ ) in $250 \mathrm{~mL}$ Erlenmeyer flasks at room temperature. Adsorption tests for the removal of MG dye were conducted by mixing $0.2 \mathrm{~g}$ activated carbon with $30 \mathrm{~mL}$ of a solution of known concentration (50-500 $\mathrm{mg} \mathrm{L}^{-1}$ at $\mathrm{pH} 7$ ) in $250 \mathrm{~mL}$ Erlenmeyer flasks at room temperature. The $\mathrm{pH}$ of each solution was adjusted with $\mathrm{HNO}_{3}$ and $\mathrm{NaOH}$. Flasks were agitated on an IKA stirrer model KS at $240 \mathrm{rpm}$ for identified time intervals, then centrifuged, and analyzed for lead ion and MG concentration using a flame atomic absorption spectrometer and UV spectrophotometer.

The amount of analyte adsorbed at any time was calculated by the difference in their initial and final concentrations. Each experiment was repeated in duplicate, and the averaged values are given as the results. The obtained data were employed to calculate the equilibrium analyte uptake capacity according to equation (1).

$$
q_{e}=v\left(C_{0}-C_{e}\right) / m,
$$

where $\mathrm{q}_{\mathrm{e}}\left(\mathrm{mg} \mathrm{g}^{-1}\right)$ is the equilibrium amount of analyte in the adsorbed phase, $\mathrm{C}_{0}$ and $\mathrm{C}_{\mathrm{e}}$ are the initial and equilibrium concentrations of analyte $\left(\mathrm{mg} \mathrm{L}^{-1}\right)$ in the aqueous solution, $\mathrm{v}$ is the volume of the solution $(\mathrm{L})$, and $\mathrm{m}$ is the sorbent dose $(\mathrm{g})$ in the mixture. The removal percent of the analytes $(\mathrm{Re} \%)$ in solution was calculated using equation (2).

$$
\operatorname{Re} \%=\left[\left(C_{0}-C_{e}\right) / C_{0}\right] \times 100
$$

\section{RESULTS AND DISCUSSION}

\section{Characterization of the prepared activated carbon}

The yield of activated carbon, which is an indication of activation process efficiency, is the amount of activated carbon produced at the end of the activation step. The total ash content of the resultant activated carbon was determined by the ASTMD2866-94 method, and the surface area was measured by BET (Brunauer-Emmett-Teller) method. The iodine number, defined as milligrams of iodine per gram of carbon, was determined by the ASTM D4607-94 method. The $\mathrm{pH}$ point of zero charge $\left(\mathrm{pH}_{\mathrm{pzc}}\right)$, which indicates the acid or basic character of the carbon surface, ${ }^{30}$ was determined. According to the procedure described by Noh and Schwarz, ${ }^{31}$ known amounts of carbon were sequentially added to a given volume of aqueous 0.1 eq $\mathrm{L}^{-1} \mathrm{NaCl}$ until the $\mathrm{pH}$ of the solute did not change with further addition of carbon. This value $\left(\mathrm{pH}_{\mathrm{pzc}}\right)$ corresponds to the $\mathrm{H}^{+}$ion concentration after all acid groups present on the surface reach their dissociativeassociative equilibrium. Characteristics of the activated carbon are presented in Table 1 .

Scanning electron micrographs (SEM) were obtained by using a scanning electron microscope (Cam Scan MV2300). Scanning electron micrographs were recorded for the sample coating with 1000x magnification (Figure 1), and they showed that the adsorbent had an irregular and porous surface, indicating relatively high surface areas. This observation is supported by the BET surface area of the activated carbon. The porous and roughened surface had large surface areas for dye molecule binding, which may prove suitable for pollutant removal.

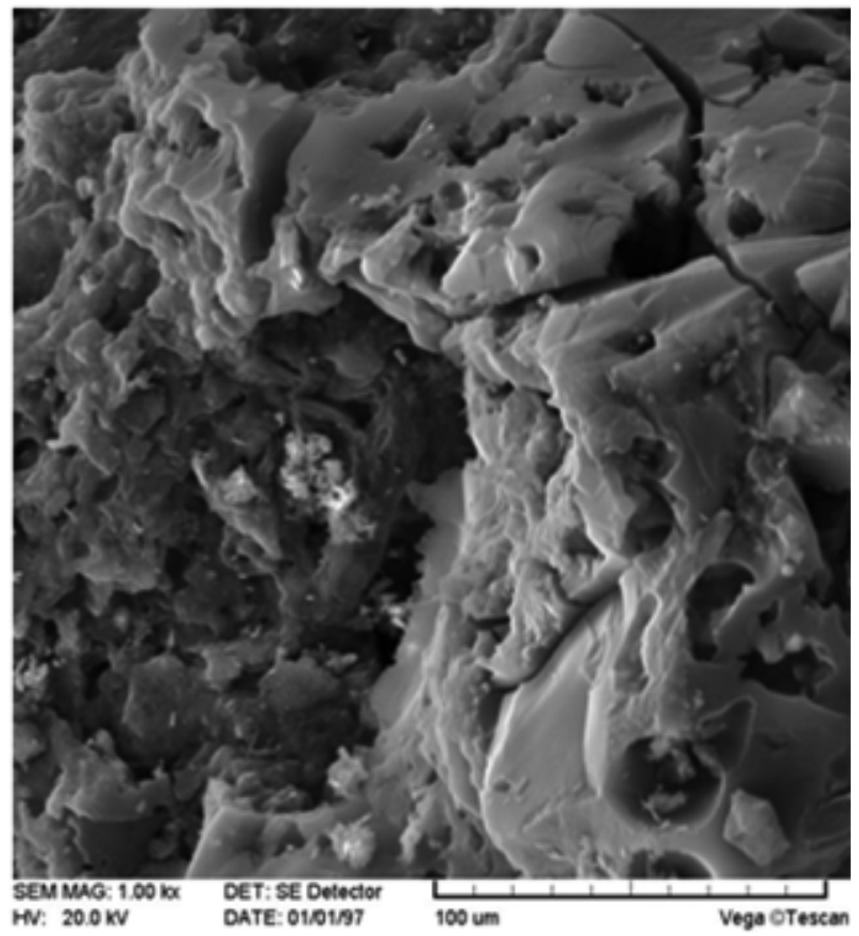

Figure 1. SEM image of produced activated carbon (magnification: 1000x)

An FTIR spectrometer (Brucker Tensor 27) was employed to determine the presence of functional groups in the activated carbon. The pellet (pressed-disk) technique was used for this purpose. The pellets were prepared using $1 \mathrm{mg}$ of the sample and $100 \mathrm{mg}$ of $\mathrm{KBr}$. The FTIR spectra displayed the presence of some absorption peaks attributed to different functional groups including carbonyl, carboxylic acid, and hydroxy groups.

\section{Effect of pH}

The $\mathrm{pH}$ of the aqueous solution is an important factor and influences the removal of heavy metal ions and dyes as well as the surface properties of the adsorbent. Therefore, it can affect the extent of adsorption..$^{32}$ For this purpose, the effect of $\mathrm{pH}$ on the removal of MG dye and lead ions were studied. The results are shown in Figure 2. The removal of $\mathrm{MG}$ dye and $\mathrm{Pb}$ (II) ions increased slowly as the $\mathrm{pH}$ increased from 2 to 8 . The $\mathrm{pHs}$ higher than 8 were not studied for the removal of $\mathrm{Pb}(\mathrm{II})$ ions because lead could precipitate as lead

Table 1. Characteristics of the produced activated carbon

\begin{tabular}{lcccc}
\hline Parameters & Bet surface area $\left(\mathrm{m}^{2} \mathrm{~g}^{-1}\right)$ & Iodine number $\left(\mathrm{mg} \mathrm{g}^{-1}\right)$ & $\mathrm{pH}_{\mathrm{pzc}}$ & Total ash $(\%)$ \\
\hline Calculated & 1158 & 840.3 & 3.2 & 52.1 \\
\hline
\end{tabular}


hydroxide at those $\mathrm{pH}$ values. Based on these results, a $\mathrm{pH}$ of 7 was selected for further studies.

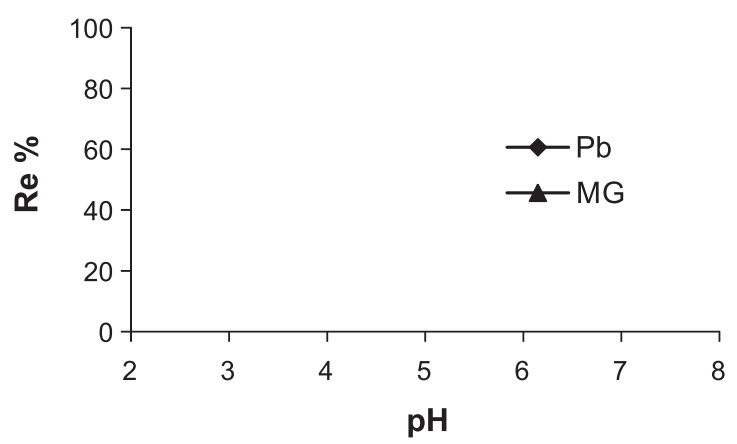

Figure 2. The effect of $\mathrm{pH}$ on the adsorption of $\mathrm{Pb}(\mathrm{II})$ ions and $M G$ dye on

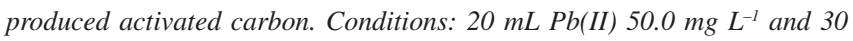
$m L M G$ dye $80.0 \mathrm{mg} \mathrm{L}^{-1}$, agitation time: $25 \mathrm{~min}$, agitation speed: $240 \mathrm{rpm}$, sorbent: $0.1 \mathrm{~g}$ for $\mathrm{Pb}(\mathrm{II})$ ions and $0.2 \mathrm{~g}$ for $\mathrm{MG}$ dye, $\mathrm{pH}-7$

The $\mathrm{pH}_{\text {zpc }}$ plays an important role in the adsorption process. ${ }^{32}$ Above the $\mathrm{pH}_{\mathrm{zpc}}$, the surface of activated carbon is negative, and there is a strong electrostatic attraction between surface groups and $\mathrm{Pb}$ (II) species. As a result, at $\mathrm{pHs}$ higher than $\mathrm{pH}_{\mathrm{zpc}}$ (3.2), the adsorption of $\mathrm{Pb}(\mathrm{II})$ ion and MG (basic or cationic dye) is high.

\section{Effect of initial concentration}

The effect of the initial concentration of $\mathrm{Pb}$ (II) ions and MG dye on adsorption was investigated for concentrations ranging from 50 to $500 \mathrm{mg} \mathrm{L}^{-1}$. The results are shown in Table 2 . It can be seen that as the initial concentration increased the removal percent decreased. However, the actual amount of $\mathrm{Pb}$ (II) ions and MG dye adsorbed per unit mass of activated carbon increased with an increase in the initial concentration. At lower concentrations, high surface areas of adsorbent vacant sites are available, leading to an increase in the concentration gradient and rate of analyte diffusion to adsorbents. At high concentrations of analytes, the available sites of adsorbents decrease, and the analyte removal percentage is dependent on the initial concentration of $\mathrm{Pb}(\mathrm{II})$ ions and $\mathrm{MG}$ dye.

\section{Effect of contact time}

The time-dependent behavior of $\mathrm{Pb}(\mathrm{II})$ ions and MG dye adsorption on activated carbon at a fixed stirring rate was evaluated for different equilibrium time intervals from 3 to $35 \mathrm{~min}$ at room temperature. The results are presented in Figure 3. It can be seen that the adsorption of $\mathrm{Pb}$ (II) ions and MG dye increases sharply, and $\sim 95 \%$ of the total $\mathrm{Pb}(\mathrm{II})$ ions and MG dye was removed within 5 and
$25 \mathrm{~min}$, respectively. The fast adsorption rate is attributed to the large external surface of the activated carbon. Further increase in contact time does not enhance the adsorption percentage. Based on these results, a contact time of $25 \mathrm{~min}$ was selected in further studies for the removal of lead ions and MG dye. The short time needed to reach equilibrium suggests that activated carbon has a very high adsorption efficiency and high value for industrial applications.

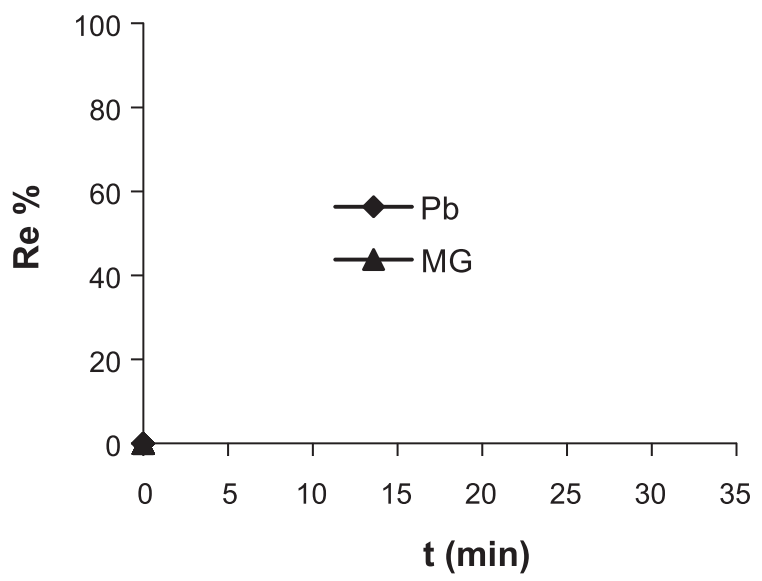

Figure 3. The effect of contact time on adsorption of $\mathrm{Pb}(\mathrm{II})$ ions and $M G$ dye on produced activated carbon. Conditions were the same as Figure 3, except for agitation time

\section{Adsorption kinetic study}

The adsorption of a solute by a solid in an aqueous solution is a phenomenon that often has complex kinetics. The adsorption rate is strongly influenced by several parameters related to the state of the solid, which generally has a very heterogeneous reactive surface, and the physico-chemical conditions under which the adsorption is performed. ${ }^{33}$ To investigate the adsorption processes of MG dye and $\mathrm{Pb}$ (II) ions on the adsorbent, pseudo-first-order and pseudo-secondorder kinetic models were studied.

\section{Pseudo-first-order model}

The pseudo-first-order model was described by Lagergren. ${ }^{34}$

$$
\frac{d q_{t}}{d t}=K_{1}\left(q_{e}-q_{t}\right)
$$

where $\mathrm{q}_{\mathrm{e}}$ and $\mathrm{q}_{\mathrm{t}}$ refer to the amount of analyte $\left(\mathrm{mg} \mathrm{g}^{-1}\right)$ at equilibrium and any time, respectively, and $K_{l}$ is the equilibrium rate constant for pseudo-first-order adsorption $\left(\mathrm{min}^{-1}\right)$.

Table 2. Effect of the initial concentration on the adsorption of $\mathrm{Pb}(\mathrm{II})$ ions and MG dye on the produced activated carbon

\begin{tabular}{|c|c|c|c|c|c|c|}
\hline \multirow{3}{*}{$\begin{array}{l}\text { Initial } \\
\text { Concentration } \\
\left(\mathrm{mg} \mathrm{L}^{-1}\right)\end{array}$} & \multicolumn{6}{|c|}{ Analyte } \\
\hline & \multicolumn{3}{|c|}{$\mathrm{Pb}$ (II) ion } & \multicolumn{3}{|c|}{ MG dye } \\
\hline & $\mathrm{C}_{\mathrm{e}}\left(\mathrm{mg} \mathrm{L}^{-1}\right)$ & $\mathrm{q}_{\mathrm{e}}\left(\mathrm{mg} \mathrm{g}^{-1}\right)$ & Removal \% & $\mathrm{C}_{\mathrm{e}}\left(\mathrm{mg} \mathrm{L}^{-1}\right)$ & $\mathrm{q}_{\mathrm{e}}\left(\mathrm{mg} \mathrm{g}^{-1}\right)$ & Removal \% \\
\hline 50 & 2.95 & 9.41 & 94.1 & 1.95 & 7.2075 & 96.1 \\
\hline 80 & 12.72 & 13.456 & 84.1 & 5.52 & 11.172 & 93.1 \\
\hline 100 & 19.2 & 16.16 & 80.8 & 8.8 & 13.68 & 91.2 \\
\hline 150 & 34.41 & 23.118 & 77.06 & 19.2 & 19.62 & 87.2 \\
\hline 200 & 50.6 & 29.88 & 74.7 & 33 & 25.05 & 83.5 \\
\hline 300 & 86.1 & 42.78 & 71.3 & 62.4 & 35.64 & 79.2 \\
\hline 500 & 171.5 & 65.7 & 65.7 & 138.5 & 54.225 & 72.3 \\
\hline
\end{tabular}


Table 3. Kinetic constants for different kinetic models

\begin{tabular}{|c|c|c|c|c|c|c|}
\hline \multirow{2}{*}{ Analyte } & \multicolumn{2}{|c|}{ Pseudo-first-order } & \multicolumn{2}{|c|}{ Pseudo-second-order } & \multicolumn{2}{|c|}{ Intra-particle diffusion } \\
\hline & $\mathrm{K}_{1}$ & $\mathrm{R}^{2}$ & $\mathrm{~K}_{2}$ & $\mathrm{R}^{2}$ & $\mathrm{~K}_{\mathrm{id}}$ & $\mathrm{R}^{2}$ \\
\hline MG dye & 0.108 & 0.993 & 0.123 & 0.999 & 0.427 & 0.984 \\
\hline $\mathrm{Pb}$ (II) ion & 0.090 & 0.963 & 0.759 & 1 & 0.116 & 0.905 \\
\hline
\end{tabular}

Integration of equation (3) for the boundary conditions $t=0$ to $t$ and $q=0$ to $q$ gives

$$
\log \left(q_{e}-q_{t}\right)=\log q_{e}-\frac{K_{1}}{2.303} t .
$$

The values of $\log \left(q_{e}-q_{t}\right)$ were linearly correlated with $t$. The plot of $\log \left(q_{e}-q_{t}\right)$ vs. $t$ should give a linear relationship, and the value of $K_{1}$ was determined from the slope of the plot (Table 3 ).

\section{Pseudo-second-order model}

The pseudo-second-order model is represented by the following differential equation. ${ }^{35}$

$$
\frac{d q_{t}}{d t}=K_{2}\left(q_{e}-q_{t}\right)^{2}
$$

where $K_{2}$ is the equilibrium rate constant of pseudo-second-order adsorption $\left(\mathrm{g} \mathrm{mg}^{-1} \mathrm{~min}^{-1}\right)$. Integrating equation (5) for the boundary condition $t=0$ to $t$ and $q=0$ to $q$ gives

$$
\frac{t}{q_{t}}=\frac{1}{K_{2} q_{e}^{2}}+\frac{1}{q_{e}} t .
$$

The slope and intercept of a plot of $t / q$ vs. $t$ were used to calculate the second-order rate constant, $K_{2}$ (Table 3 ). The correlation coefficients of all the examined data were found to be very high $\left(R^{2}\right.$ $\geq 0.999)$. This shows that the model can be applied for the entire adsorption process and confirms that the sorption of analytes on activated carbon prepared from lemon peels follows the pseudosecond-order kinetic model.

\section{Intra-particle diffusion model}

The adsorbate species are most probably transported from the bulk of the solution into the solid phase via an intra-particle diffusion process, which is often the rate-limiting step in many adsorption processes. The possibility of intra-particle diffusion is explored using the intra-particle diffusion model. ${ }^{36}$

$$
q_{t}=K_{i d} t^{1 / 2}+C
$$

where $\mathrm{C}$ is the intercept and $\mathrm{k}_{\mathrm{id}}$ is the intra-particle diffusion rate constant. The values of $\mathrm{k}_{\mathrm{id}}, \mathrm{C}$, and the corresponding linear regression correlation coefficient, $\mathrm{R}^{2}$, are given in Table 3 . The intra-particle rate constants calculated for MG dye and $\mathrm{Pb}$ (II) ions are 0.427 and 0.116 $\mathrm{mg} \mathrm{g}^{-1} \mathrm{~min}^{-1 / 2}$, respectively. These high values show that activated carbon has a high tendency for the removal of $\mathrm{MG}$ dye and $\mathrm{Pb}$ (II) ions. ${ }^{37,38}$

\section{Adsorption equilibrium study}

Equilibrium data, commonly known as adsorption isotherms, are basic requirements for the design of adsorption systems. To discover the adsorption capacity of the prepared activated carbons, Langmuir and Freundlich isotherms were applied, and the constants of the isotherm equations were calculated.

\section{Langmuir isotherm}

The Langmuir equation, which is valid for monolayer adsorption on a completely homogenous surface with a finite number of identical sites and negligible interaction between adsorbed molecules, is represented in the linear form as follows: ${ }^{39}$

$$
\frac{C_{e}}{q_{e}}=\frac{1}{Q^{0} b}+\frac{C_{e}}{Q^{0}}
$$

where $\mathrm{Q}^{0}$ is the theoretical maximum adsorption capacity $\left(\mathrm{mg} \mathrm{g}^{-1}\right)$ and $\mathrm{b}$ is the constant related to the free energy of adsorption ( $\mathrm{I} \mu$ $\exp (-\Delta G / R T)$ ).

Figures 4 and 5 show the Langmuir plots for the adsorption of $\mathrm{Pb}$ (II) ions and MG dye at room temperature. The values of $Q^{0}, b$, and the correlation coefficients for Langmuir isotherms are presented in Table 4.

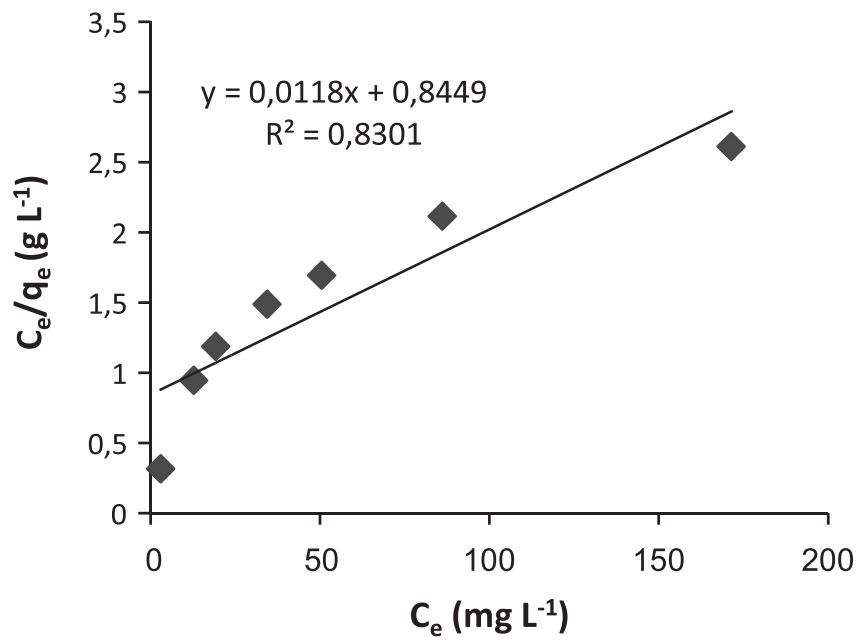

Figure 4. Langmuir adsorption isotherm of $P b(I I)$ ions on produced activated carbon at room temperature

The essential characteristics of the Langmuir isotherm can also be expressed in terms of a dimensionless constant of separation factor or equilibrium parameter, $\mathrm{R}_{\mathrm{L}},{ }^{40}$ which is defined as

$$
R_{L}=\frac{1}{1+b C_{0}},
$$

where $\mathrm{b}$ is the Langmuir constant and $\mathrm{C}_{0}$ is the initial concentration of $\mathrm{Pb}$ (II) ion. The $\mathrm{R}_{\mathrm{L}}$ value indicates the shape of the isotherm. $\mathrm{R}_{\mathrm{L}}$ values between 0 and 1 indicate favorable adsorption, while $R_{L} \geq 1$ or $\mathrm{R}_{\mathrm{L}}=0$ indicate unfavorable and irreversible adsorption isotherms. $R_{L}$ values are given in Table 5. $R_{L}$ at different concentrations between 0 and 1 indicates a highly favorable adsorption. 


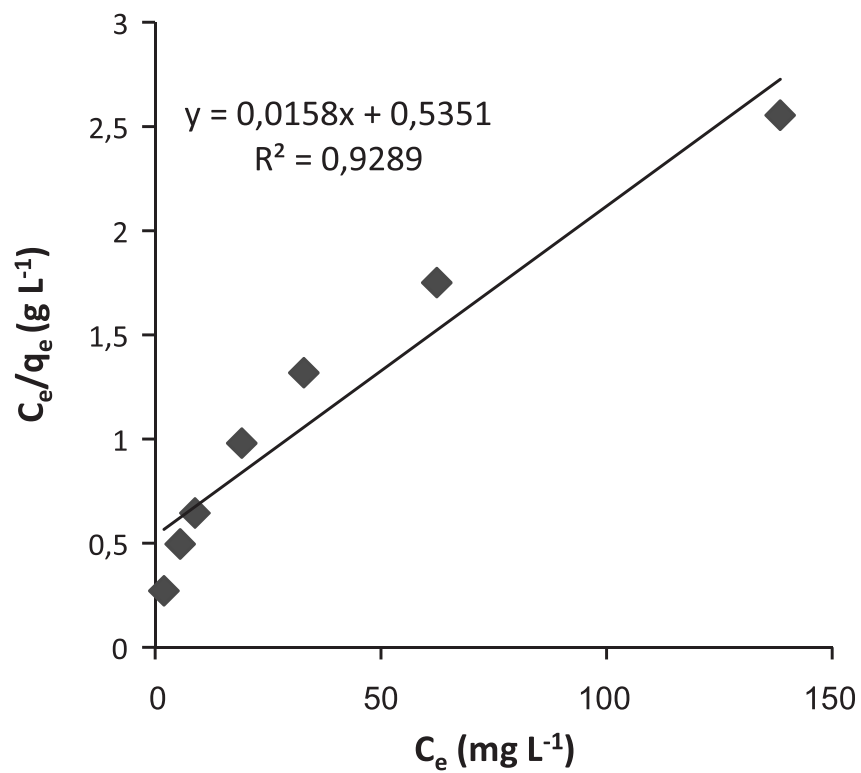

Figure 5. Langmuir adsorption isotherm of $M G$ dye on produced activated carbon at room temperature

Table 4. Freundlich and Langmuir isotherm constants for $\mathrm{Pb}$ (II) ions and MG dye adsorption on the produced activated carbon

\begin{tabular}{lcccccccc}
\hline \multirow{2}{*}{ Analyte } & \multicolumn{3}{c}{ Langmuir } & & \multicolumn{3}{c}{ Freundlich } \\
\cline { 2 - 4 } \cline { 6 - 8 } & $\mathrm{Q}^{0}$ & $\mathrm{~B}$ & $\mathrm{R}^{2}$ & & $\mathrm{~K}_{\mathrm{f}}$ & $1 / \mathrm{n}$ & $\mathrm{R}^{2}$ \\
\hline MG dye & 66.67 & 0.028 & 0.928 & & 5.0 & 0.472 & 0.997 \\
$\mathrm{~Pb}(\mathrm{II})$ ion & 90.91 & 0.013 & 0.830 & & 4.43 & 0.494 & 0.951 \\
\hline
\end{tabular}

Table 5. The $\mathrm{R}_{\mathrm{L}}$ values for $\mathrm{MG}$ dye and $\mathrm{Pb}$ (II) ions

\begin{tabular}{ccc}
\hline \multirow{2}{*}{$\mathrm{C}_{0}$} & \multicolumn{2}{c}{$\mathrm{R}_{\mathrm{L}}$} \\
\cline { 2 - 3 } & MG dye & $\mathrm{Pb}(\mathrm{II})$ ion \\
\hline 50 & 0.42 & 0.61 \\
80 & 0.31 & 0.49 \\
100 & 0.26 & 0.43 \\
150 & 0.19 & 0.34 \\
200 & 0.15 & 0.28 \\
300 & 0.11 & 0.20 \\
500 & 0.07 & 0.13 \\
\hline
\end{tabular}

\section{Freundlich isotherm}

The Freundlich isotherm is derived by assuming a heterogeneous surface with a nonuniform distribution of heat of sorption over the surface. It can be expressed in the linear form as follows: ${ }^{41}$

$$
\log q_{e}=\log K_{f}+\frac{1}{n} \log C_{e}
$$

where $K_{f}\left(\mathrm{~L} \mathrm{mg}^{-1}\right)$ and $n$ are isotherm constants that indicate the capacity and intensity of the adsorption, respectively. The linear plot of $\log q_{e}$ vs. $\log C_{e}$ indicates that adsorption of $\mathrm{Pb}(\mathrm{II})$ ions and $\mathrm{MG}$ dye also follows the Freundlich isotherm. Table 4 shows the Freundlich adsorption isotherm constant and correlation coefficients. The value of $1 / n$ for the Freundlich isotherm was found to lie between 0 and 1 , indicating that $\mathrm{MG}$ dye and $\mathrm{Pb}$ (II) ions are favorably adsorbed by the activated carbon prepared at room temperature. ${ }^{33}$

\section{CONCLUSION}

The present study shows that the lemon peel can be effectively used as an adsorbent for the removal of MG dye and $\mathrm{Pb}$ (II) ions from wastewater. The equilibrium data were found to be well represented by the Freundlich and Langmuir isotherms, and the maximum adsorption capacity of $\mathrm{Pb}$ (II) ions and $\mathrm{MG}$ dye on the produced activated carbon were 90.91 and $66.67 \mathrm{mg} \mathrm{g}^{-1}$, respectively. Figure 3 showed that quantitative removal of MG dye and $\mathrm{Pb}(\mathrm{II})$ ions was obtained within a very short time. This result is very interesting because equilibrium time is a very important parameter for wastewater treatment applications. Adsorption rate constants and capacities were very fast and high, respectively, compared to other methods for the removal of pollutants from aqueous solution. Low cost, rapid adsorptive ability, agricultural waste, and regeneration facility of these adsorbents offer a promising technique for industrial wastewater clean up. The adsorption capacities were compared to other adsorbents ${ }^{1,13,19-29}$ and are presented in Table 6.

Table 6. Comparison of adsorption capacity of prepared activated carbon with activated carbons prepared from a different precursor

\begin{tabular}{lccc}
\hline Adsorbent & Analyte & $\mathrm{Q}^{0}\left(\mathrm{mg} \mathrm{g}^{-1}\right)$ & Ref. \\
\hline Ceiba pentandra hulls & $\mathrm{Pb}(\mathrm{II})$ ion & 25.5 & 1 \\
Amygdalus Scoparia shell & $\mathrm{Pb}(\mathrm{II})$ ion & 36.63 & 19 \\
Sea-buckthorn stones & $\mathrm{Pb}(\mathrm{II})$ ion & 51.81 & 20 \\
Tamarind wood & $\mathrm{Pb}(\mathrm{II})$ ion & 43.85 & 21 \\
Pine cone & $\mathrm{Pb}(\mathrm{II})$ ion & 27.53 & 22 \\
Hazelnut husks & $\mathrm{Pb}(\mathrm{II})$ ion & 13.05 & 23 \\
Coconut shell & $\mathrm{Pb}(\mathrm{II})$ ion & 26.5 & 24 \\
Limon shell & $\mathrm{Pb}(\mathrm{II})$ ion & 90.91 & This work \\
Activated carbon commercial grade & $\mathrm{MG}$ dye & 8.27 & 13 \\
Activated carbon laboratory grade & $\mathrm{MG}$ dye & 42.18 & 13 \\
Activated charcoal & MG dye & 0.18 & 25 \\
Arundo donax root & MG dye & 9.35 & 26 \\
Ricinus communis & MG dye & 27.78 & 27 \\
Caulerpa racemosa var. cylindracea & MG dye & 25.67 & 28 \\
Borassus aethiopum flower biomass & MG dye & 48.48 & 29 \\
Limon shell & MG dye & 66.67 & This work \\
\hline
\end{tabular}

\section{REFERENCES}

1. Madhava-Rao, M.; Chandra-Rao, G. P.; Seshaiah, K.; Wang, M. C.; Waste Manage. 2008, 28, 849.

2. Nevine-Kamal, A.; Desalination 2008, 223, 152.

3. Hsu, P. C.; Guo, Y. L.; Toxicology 2002, 180, 33.

4. Crini, G.; Peindy, H. N.; Gimbert, F.; Robert, C.; Sep. Purif. Technol. 2007, 53, 97.

5. Berberidou, C.; Poulios, I.; Xekoukoulotakis N. P.; Mantzavinos, D.; Appl. Catal., B 2007, 74, 63.

6. Hamdaoui, O. ; Chiha, M.; Naffrechoux, E.; Ultrason. Sonochem. 2008, 15,799 .

7. Ozdes, D.; Duran, C.; Senturk, H. B.; J. Environ. Manage. 2011, 92, 3082.

8. Salem, A.; Sene, R.; Chem. Eng. J. 2011, 174, 619.

9. Su, Q.; Pan B.; Pan, B.; Zhang, Q.; Zhang, W.; Lv, L.; Wang, X.; Wu, J.; Zhang, Q.; Sci. Total Environ. 2009, 407, 5471.

10. Tsunekawa, M.; Ito, M.; Yuta, S.; Tomoo, S.; Hiroyoshi, N.; J. Hazard. Mater. 2011, 191, 388. 
11. Aziz, H. A. ; Adlan, M. N.; Ariffn, K. S.; Bioresource Technol. 2008, 99 , 1578.

12. Zhu, H. Y.; Jiang, R.; Fu, Y. Q.; Jiang, J. H.; Xiao, L.; Zeng, G. M.; App. Surf. Sci. 2011, 258, 1337

13. Mall, I. D.; Srivastava, V. C.; Agarwal, N. K.; Mishra, I. M.; Colloids Surf., A 2005, 264, 17.

14. Uçurum, M.; Fuel 2009, 88, 1460.

15. Salam, M. A.; Colloid Surf., A 2013, 419, 69.

16. Shao, W.; Chen, L. Lü, L.; Luo, F.; Desalination 2011, 265, 177.

17. Vasanth Kumar, K.; Dyes Pigm. 2007, 74, 595.

18. Bhatnagar, A.; Minocha, A. K.; Sillanpaa, M.; Biochem. Eng. J. 2010, 48,181 .

19. Mohammadi, S. Z.; Karimi, M. A.; Afzali, D.; Mansouri, F.; Cent. Eur J. Chem. 2010, 8, 1273 .

20. Mohammadi, S. Z.; Karimi, M. A.; Afzali, D.; Mansouri, F.; Desalination 2010, 262, 86.

21. Acharya, J.; Sahu, J. N.; Mohanty, C. R.; Meikap, B.C.; Chem. Eng. J. 2009, 149, 249.

22. Momcilovic, M.; Purenovic, M.; Bojic, A.; Zarubica A.; Randelovic, M.; Desalination 2011, 276, 53

23. Imamoglu, M.; Tekir, O.; Desalination 2008, 228, 108.

24. Sekar, M.; Sakthi, V.; Rengaraj, S.; J. Colloid Interf. Sci. 2004, 279, 307.
25. Iqbal, M. J.; Ashiq, M.N.; J. Hazard. Mater. 2007, 139, 57.

26. Zhang, J.; Li, Y.; Zhang, C.; Jing, Y.; J. Hazard. Mater. 2008, 150, 774.

27. Santhi, T.; Manonmani, S.; Smith, T.; J. Hazard. Mater. 2010, 179, 178.

28. Bekci, Z.; Seki, Y.; Cavas, L.; J. Hazard. Mater. 2009, 161, 1454.

29. Nethaji, S.; Sivasamy, A.; Thennarasu, G.; Saravanan, S.; J. Hazard. Mater. 2010, 181, 271.

30. Radovic, L. R.; Chemistry and physics of carbon. Taylor \& Francis: New York, 2008.

31. Noh, J. S.; Schwarz, J. A.; Colloid Interf. Sci. 1989, 130, 157.

32. Sreejalekshmi, K. G.; Krishnan, K. A.; Anirudhan, T. S.; J. Hazard. Mater. 2009, 161, 1506.

33. Amin, N. K.; J. Hazard. Mater. 2009, 165, 52.

34. Lagergren, S.; Handlingar 1898, $24,1$.

35. Mckay, G.; Ho, Y. S.; Process Biochem. 1999, 34, 451

36. Jnr, M. H.; Spiff, A. I.; Electron. J. Biotechnol. 2005, 8, 162.

37. Ghaedi, M.; Tavallali, H.; Sharifi, M.; Nasiri Kokhdan, S.; Asghari, A.; Spectrochim. Acta, Part A 2012, 86, 107.

38. Gupta, V. K.; Ali, I.; Sep. Purif. Technol. 2000, 18, 131.

39. Langmuir, I.; J. Am. Chem. Soc. 1916, 38, 2221.

40. Madhava Rao, M.; Ramana, D. K.; Seshaiah, K.; Wang, M. C.; Chang Chien, S. W. ; J. Hazard. Mater. 2009, 166, 1006.

41. Freundlich, H. M. F.; Z. Phys. Chem. 1906, 57, 385. 